\title{
Long-Term Wind Characteristics at Selected Locations in Mauritius for Power Generation
}

\author{
A. Z. Dhunny, M. R. Lollchund, and S. D. D. V. Rughooputh \\ Department of Physics, University of Mauritius, 80837 Reduit, Mauritius \\ Correspondence should be addressed to M. R. Lollchund; r.lollchund@uom.ac.mu
}

Received 30 June 2015; Accepted 30 August 2015

Academic Editor: Adrian Ilinca

Copyright (C) 2015 A. Z. Dhunny et al. This is an open access article distributed under the Creative Commons Attribution License, which permits unrestricted use, distribution, and reproduction in any medium, provided the original work is properly cited.

Interests in wind energy have gained impetus in many developed and developing countries worldwide during the last three decades. This is due to awareness of the population about the depletion of fossil fuels as well as Government campaigns and initiatives to encourage the use of renewable sources of energy. This work focuses on the wind energy potential at two selected locations (Plaisance and Vacoas) in Mauritius. The emphasis is to assess whether small-wind turbines have a potential in these regions for generation of power for domestic applications. Such wind turbines can range in size from $400 \mathrm{~W}$ to $10 \mathrm{~kW}$ depending on the amount of electricity to be generated. The assessment is based on the correlation of the local wind speed data to a two-parameter Weibull probability distribution in order to effectively estimate the average wind power density of the sites. Nearly 40 years of mean wind speed data is utilized. Of the two sites investigated it is found that Plaisance yielded the highest wind velocity (as compared to Vacoas). The study also estimates the energy output of six commercial small-wind turbines of capacity ranging from $1 \mathrm{~kW}$ to $3 \mathrm{~kW}$ at these two sites, placed at multiple heights.

\section{Introduction}

Mauritius is an island situated in the southwest region of the Indian Ocean. Its mainland covers an area of $1865 \mathrm{~km}^{2}$ and it has a coastline of $330 \mathrm{~km}$. Mauritius has a population of around 1.27 million inhabitants and a growth rate of $1 \%$ per annum [1]. The Central Electricity Board (CEB) which is the sole distributor of power for the consumers is having difficulty in coping with the high demand [2]. A forecasting has shown that the energy demand keeps on growing at around 5\% annually. Therefore, to delve into other sources of economic and more importantly clean energy is becoming a necessity for the CEB. Two wind farm projects which are currently under constructions are expected to contribute $77 \mathrm{GWh}$ of energy while an additional $16 \mathrm{GWh}$ is also envisaged from a solar photovoltaic (PV) farm project. The Government's Maurice Ile Durable (MID) initiative [3], along with promotional incentives for renewable energy projects, is greatly encouraging the adoption of small-scale power generators, such as PV and small-wind turbines, in individual households for their domestic use. This category of electricity consumers represents around $30 \%$ of the demand [2]. Installation of small-wind turbines by individuals is more popular compared to PV cells due to the relatively low installation and maintenance costs [4]. This work focuses on the assessment of wind resource at two selected sites (Plaisance and Vacoas) in Mauritius (see Figure 1). The objective is to evaluate the potential of small-wind turbines which operate with wind speed in the range of 3.0 to $20 \mathrm{~m} / \mathrm{s}$ and which can generate between 1.5 and 2.5 MWh of yearly electrical power [5]. According to the CEB, the average specific consumption of a typical household in Mauritius is around 2 MWh per year [2]. Hence, depending on the average wind speed in the area, a wind turbine rated in the range of $1 \mathrm{~kW}$ to $10 \mathrm{~kW}$ could $a$ priori make a significant contribution to this demand. To the author's knowledge no study has been performed to assess the wind potential in localized urban regions in Mauritius for the placement of such rated small-wind turbines.

The assessment of wind energy potential of a region requires long-term data related to the wind speed and an accurate determination of its distribution. The variations in wind speed can be characterized by two functions which are 


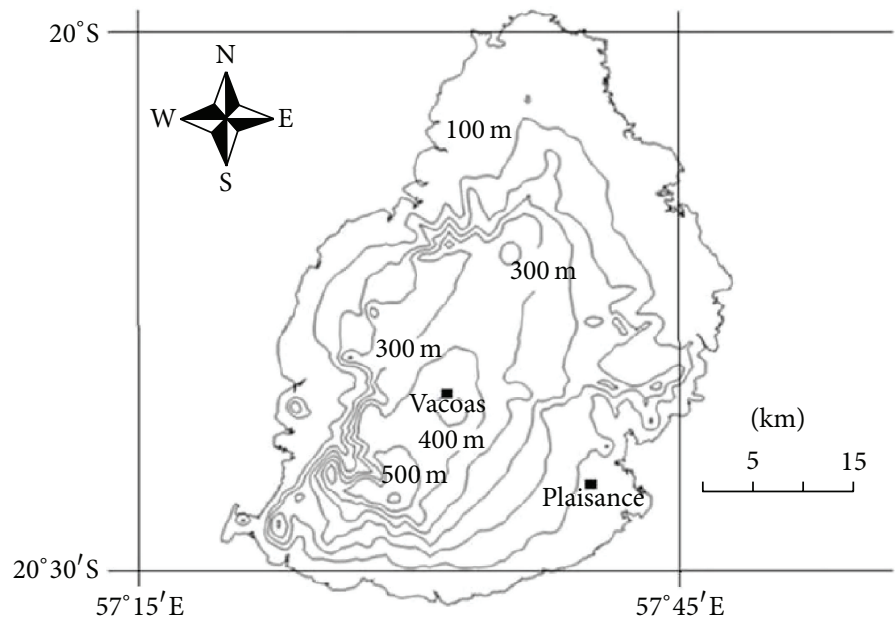

FIGURE 1: A map of the main island of Mauritius showing the locations of Vacoas and Plaisance and their respective elevations above sea level.

the probability density function (PDF) and the corresponding cumulative density function (CDF). Dhunny et al. [6] have tested long-term wind speed data at Plaisance and Vacoas with seven standard statistical distributions, Burr, Weibull, Lognormal, Normal, Rayleigh, Gamma, and Frechet, and concluded that wind speed data at both locations were more significantly represented by the Weibull and Burr distributions according to the goodness of fit tests. For the study presented in this paper, the Weibull distribution will be solely considered due to its great flexibility and simplicity in the computation of wind power [7]. It is worthwhile to mention that the Weibull PDF has also been employed in the analysis of the wind energy potential for different regions in countries such as Tunisia [8], Eastern Mediterranean [9], Nigeria [10], Turkey [11], Iran [12], Columbia [13], and coastal areas of Jiwani, Pakistan [14]. It is also important to get an estimate of the expected annual energy output of some typical small commercial wind turbines as a function of the annual average wind speed. The authors believe that this information will be helpful to the Government and any relevant organization in making an informed decision with regard to investment in wind energy resource for domestic use at these two mentioned sites in Mauritius.

\section{Theoretical Background}

2.1. Weibull Probability Distribution of Wind Speed. The Weibull probability density function (WPDF), $f(v)$, for the wind data indicates the probability that the wind will blow at a given speed $v$. It is a two-parameter distribution which can be expressed as

$$
f(v)=\frac{k}{c}\left(\frac{v}{c}\right)^{k-1} \exp \left[-\left(\frac{v}{c}\right)^{k}\right]
$$

where $c$ is the Weibull scale parameter (the same dimension as $v$ ) which basically indicates the wind regime at a certain location and $k$ is a dimensionless Weibull shape parameter [15].
The cumulative distribution function $F(v)$, which is the integral of $f(v)$ in the range of $(0, v)$, is expressed as

$$
F(v)=1-\exp \left[-\left(\frac{v}{c}\right)^{k}\right]
$$

The mean and variance are, respectively, represented as

$$
\begin{aligned}
\bar{v} & =E(v)=c \Gamma\left(1+\frac{1}{k}\right), \\
\operatorname{Var}(v) & =c^{2}\left[\Gamma\left(1+\frac{2}{k}\right)-\Gamma^{2}\left(1+\frac{1}{k}\right)\right],
\end{aligned}
$$

where $\Gamma$ is the Gamma function.

To estimate the parameters $k$ and $c$ for a given set of measured velocity data, numerous methods have been proposed in the literature [16]. In this work, the Maximum Likelihood Estimation (MLE) was employed. The MLE of a variable, say, $x$, in a given function $g(x)$ is defined as the value of $x$ that maximizes the likelihood of $g(x)$ or, equivalently, the logarithm of the likelihood $g(x)$. This reduces the occurrence of an important number of unlikely outcomes for $x$. The likelihood function for the WPDF is the joint density of $n$ random variables, say, $v_{1}, v_{2}, v_{3}, \ldots, v_{n}$, and is given by

$$
\begin{aligned}
Z & {\left[v_{1}, v_{2}, \ldots, v_{n}, k, c\right] } \\
& =\prod_{i=1}^{n}\left(\frac{k}{c}\right)\left(\frac{v_{i}}{c}\right)^{k-1} \exp \left[-\left(\frac{v_{i}}{c}\right)^{k}\right] .
\end{aligned}
$$

On taking the logarithm of (4), differentiating with respect to $k$ and $c$ in turn and performing some simplifications we obtain the estimating equation

$$
\frac{\sum_{i=1}^{n} v_{i}^{k} \ln v_{i}}{\sum_{i=1}^{n} v_{i}^{k}}-\frac{1}{k}-\frac{1}{n} \sum_{i=1}^{n} \ln v_{i}=0 .
$$

Parameter $k$ of the Weibull distribution is easily obtained when solving (5) by the use of a standard iterative method 
such as the Newton-Raphson technique. Once $k$ is computed, $c$ can be estimated using

$$
c=\frac{1}{n} \sum_{i=1}^{n} v_{i}^{k} .
$$

2.2. Wind Speed Variation with Height. Wind speed data are normally measured at a certain height and, in most cases, the wind turbine hub is placed at a different height. In order to adjust the measured wind speed data to the level of the wind turbine hub, the power law is the most common expression accepted in the literature [17]. This law describes the vertical variation of wind speed and is formulated as

$$
v(h)=v_{0}\left(\frac{h}{h_{0}}\right)^{\alpha},
$$

where $v(h)$ is the wind speed at the hub height $h, v_{0}$ is the wind speed at measured height $h_{0}$, and $\alpha$ is the surface roughness coefficient. The value for $\alpha$ varies from 0.1 over the tops of steep hills to 0.25 in sheltered locations. For flat coastal regions, $\alpha$ is taken as $0.143(1 / 7)$ which is the typical value used in most research works [18]. According to Ucar and Balo [11] and Oyedepo et al. [19], the value of $\alpha$ for a particular wind condition can in general be computed from the empirical expression

$$
\alpha=\frac{\left[0.37-0.088 \ln \left(v_{0}\right)\right]}{\left[1-0.088 \ln \left(h_{0} / 10\right)\right]} .
$$

As the wind velocity varies with height, it is evident that the Weibull parameters also are functions of hub height. Oyedepo et al. [19] provide the following expressions:

$$
\begin{aligned}
& c(h)=c_{0}\left(\frac{h}{h_{0}}\right)^{\alpha}, \\
& k(h)=\frac{k_{0}\left[1-0.088 \ln \left(h_{0} / 10\right)\right]}{[1-0.088 \ln (h / 10)]},
\end{aligned}
$$

where $c_{0}$ and $k_{0}$ are, respectively, the scale factor and shape parameter at the measured height $h_{0}$.

\subsection{Estimation of Wind Power and Energy Output of a Wind} Turbine. The wind power $P_{\text {wind }}(v)$ that can be captured by a wind turbine is given by the product of the mass flow rate entering the rotor blades of the wind turbine and the kinetic energy per unit mass in the wind. It is estimated by

$$
P_{\text {wind }}(v)=\frac{1}{2} \rho A v^{3}
$$

where $\rho$ is the mean air density (assumed to be $1.225 \mathrm{~kg} / \mathrm{m}^{3}$ in this study) and $A$ is the swept area of the rotor blades. Correspondingly, the average wind power density of a site, based on the WPDF, can be obtained using the expression

$$
P_{D}=\frac{1}{2} \rho c^{3} \Gamma\left(1+\frac{3}{k}\right) \text {. }
$$

TABLE 1: The geographical coordinates and altitudes for each site.

\begin{tabular}{lcc}
\hline Site & Plaisance & Vacoas \\
\hline Location & Southeast coast & Central plateau \\
Longitude & $57^{\circ} 40^{\prime} \mathrm{E}$ & $57^{\circ} 29^{\prime} \mathrm{E}$ \\
Latitude & $20^{\circ} 25^{\prime} \mathrm{S}$ & $20^{\circ} 17^{\prime} \mathrm{S}$ \\
Altitude above sea level & $55 \mathrm{~m}$ & $425 \mathrm{~m}$ \\
\hline
\end{tabular}

The instantaneous electrical energy $W$ generated by a wind turbine depends on the efficiency and the instantaneous local wind speed. Ettoumi et al. [20] provide the expression

$$
W(v)=P_{\text {wind }}(v) g(v) f(v),
$$

where $g(v)$ is the efficiency of the turbine at speed $v$ (as given by the manufacturer). The mean annual energy output of the wind turbine can then be computed using

$$
E_{\text {out }}=N_{h} \int_{v_{\text {in }}}^{v_{\text {out }}} W(v) d v,
$$

where $N_{h}$ is the number of hours in a year and $v_{\text {in }}$ and $v_{\text {out }}$ are the cut-in and cut-off wind speeds of the turbine, respectively [13].

\section{Sites Location and Wind Data}

The main island of Mauritius spans around $60 \mathrm{~km}$ in length and $45 \mathrm{~km}$ in width and is located in the southwest tropical region of the Indian Ocean. Being of volcanic origin, its topography consists of a central plateau which is about 500 meters above sea level and gradually rising towards the southwest where it reaches its highest point at about 700 meters above sea level. This plateau is surrounded by a chain of mountains and some isolated peaks. Urban areas are mostly concentrated on the central plateau and coastal regions. The island of Mauritius enjoys a mild tropical maritime climate throughout the year. The meteorological conditions along the coasts are practically the same but cooler over the central plateau [1]. Table 1 displays the altitudes above sea level and geographical coordinates for both regions, and Figure 1 depicts their location in the island.

The Mauritius Meteorological Services (MMS) is the authorized Government organization for all meteorological activities in the island. Its endeavor is to provide accurate and timely weather information and meteorological products for the general welfare of the citizens and is also the Early Warning Center for natural disasters affecting the Republic of Mauritius. The MMS maintains a network of surface synoptic stations, agrometeorological and upper air stations which are fairly well distributed over the island. It has in its database, stored at the Utah Data Climate Center, over 40 years of mean wind speed data records which were measured at a height of $10 \mathrm{~m}$ above ground level. The prevailing trade winds over the island blow predominantly from the east with an average speed of $\sim 5 \mathrm{~m} / \mathrm{s}$. Occasionally, during the peak winter months of July and August, with the passage of strong anticyclones, wind gusts are likely to reach $25 \mathrm{~m} / \mathrm{s}$ in some exposed areas [21].

This study utilizes the wind data for the two selected sites. Data obtained for Vacoas is from 1 July 1977 to 30 July 2013, 


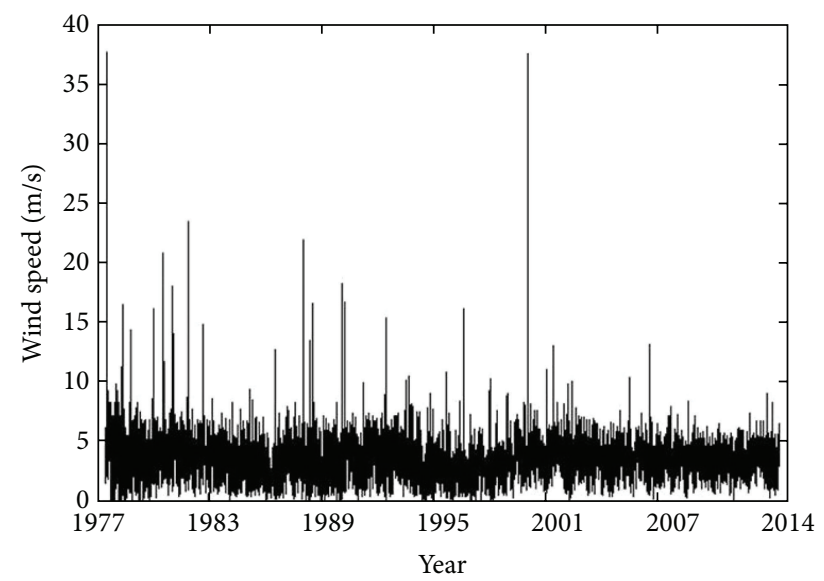

(a) Wind time series

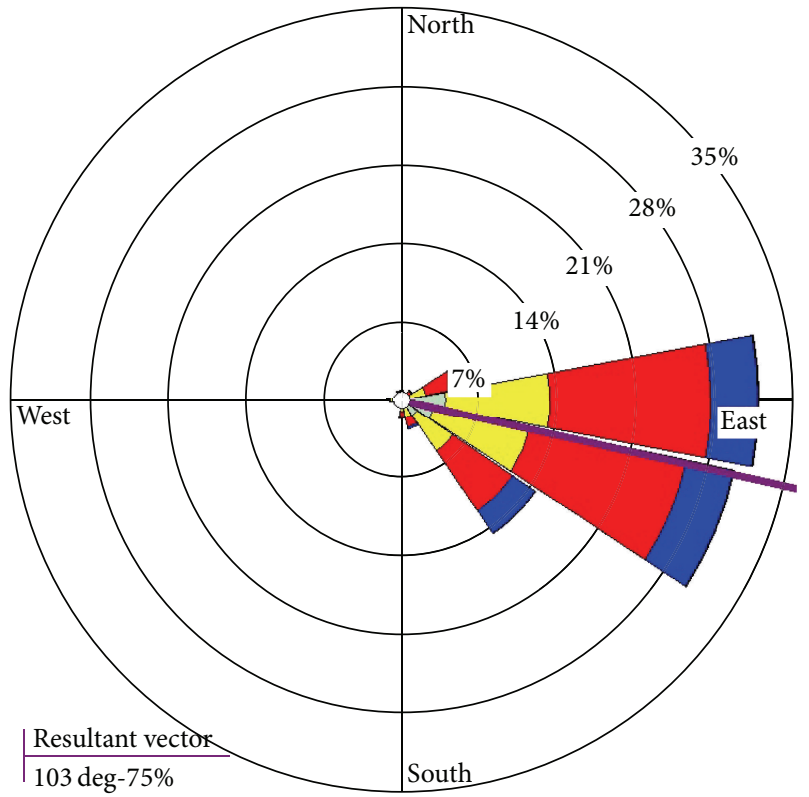

Wind speed $(\mathrm{m} / \mathrm{s})$

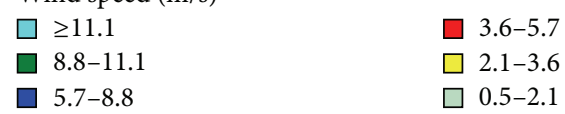

Calms: $4.52 \%$

(b) Wind rose

FIGURE 2: Daily mean wind data at Vacoas at $10 \mathrm{~m}$ above ground level from 1 June 1977 to 31 July 2013.

while data for Plaisance is from 1 January 1973 to 30 July 2013. The AWS [22] wind resource assessment handbook was used as a guide for qualitative data filtering; the data were checked thoroughly for homogeneity, outliers, and missing records before being processed for the study. Errors and missing data as well as cyclonic winds (wind exceeding $40 \mathrm{~m} / \mathrm{s}$ ), according to the Beaufort Wind Scale table [23], were eliminated. These represent $2 \%$ of the complete dataset. The time-series plots of the filtered data and corresponding wind roses are, respectively, displayed in Figures 2 and 3. The whole dataset for both stations is statistically described in Table 2. It can

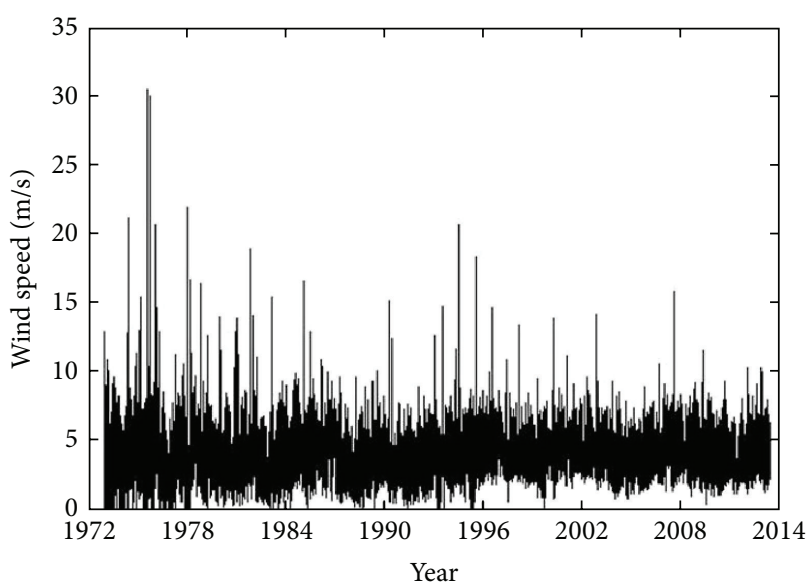

(a) Wind time series

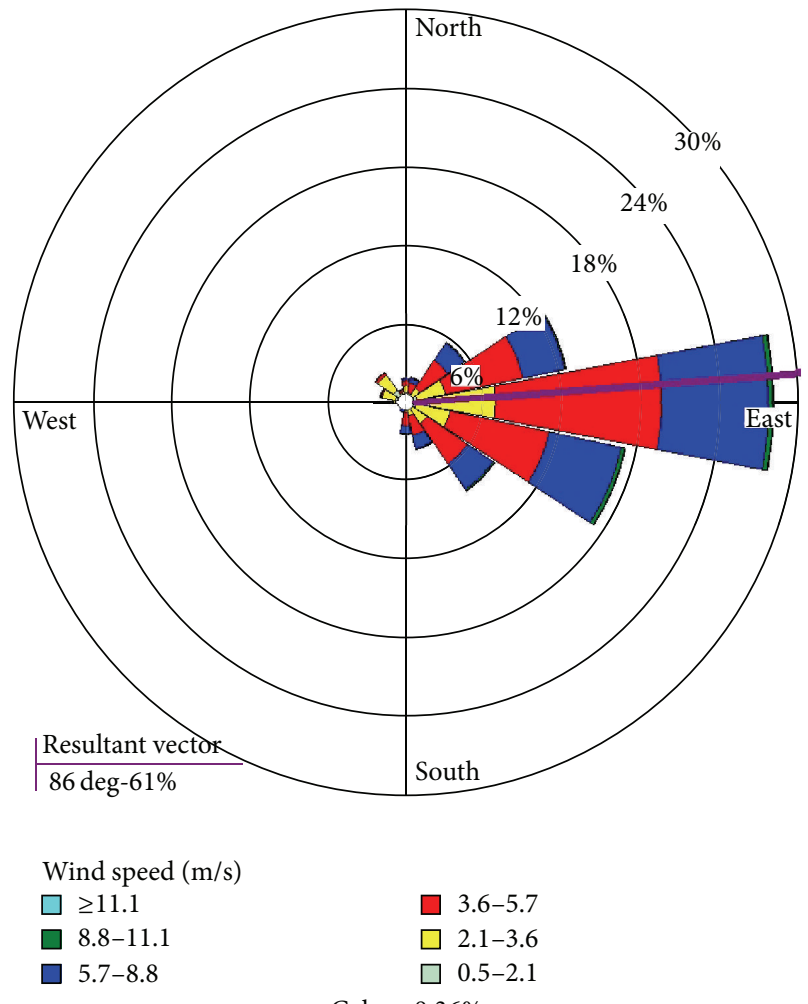

Calms: $8.36 \%$

(b) Wind rose

FIgure 3: Daily mean wind data at Plaisance at $10 \mathrm{~m}$ above ground level from 1 June 1973 to 31 July 2013.

be observed that the mean value of the wind speed is higher for Plaisance than for Vacoas. The Standard Deviation (SD), which describes by how much the data differ from the mean, is nearly the same for both stations.

\section{Results and Discussion}

The methodology discussed in Section 2 is applied to the wind data described in Section 3. It should be mentioned that wind speeds greater than $15 \mathrm{~m} / \mathrm{s}$ are truncated to remove 

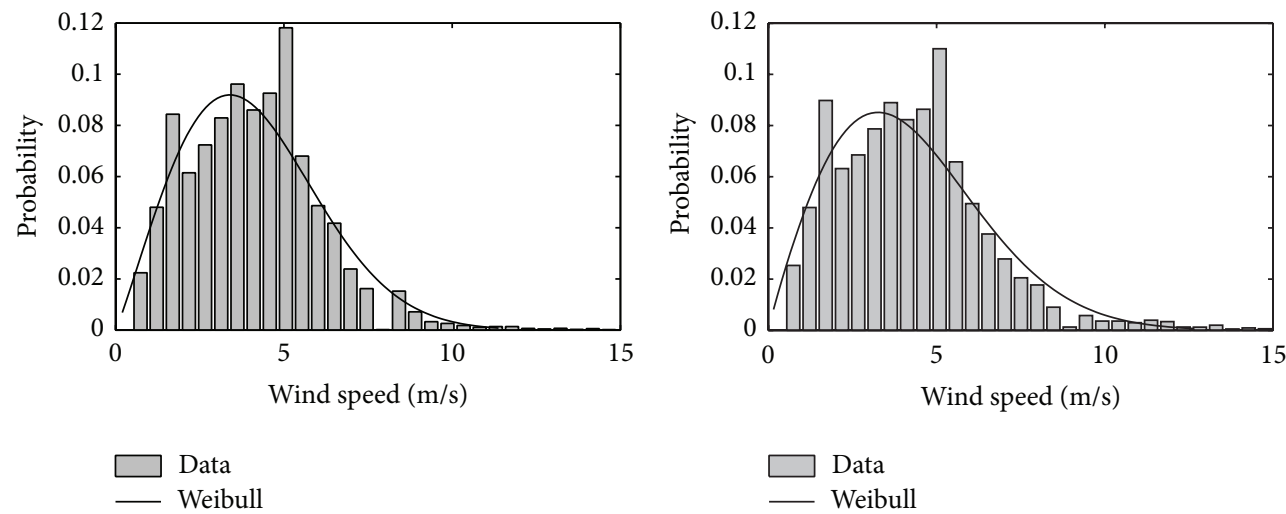

(b) February $(\bar{v}=3.99 \mathrm{~m} / \mathrm{s})$
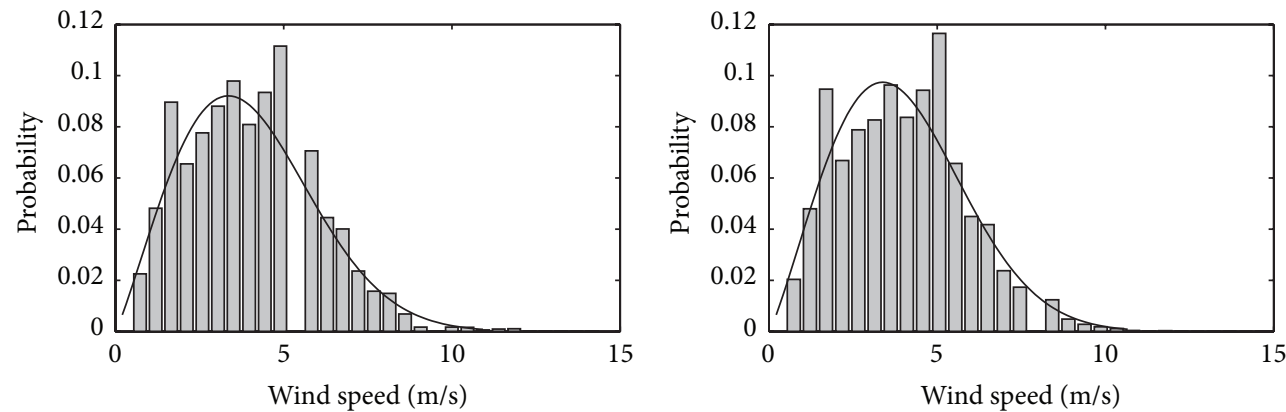

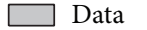

__ Weibull

(c) $\operatorname{March}(\bar{v}=3.73 \mathrm{~m} / \mathrm{s})$

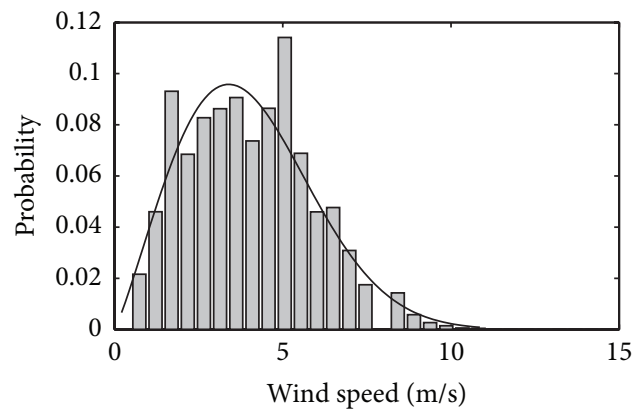

$\square$ Data

Weibull

(e) $\operatorname{May}(\bar{v}=3.81 \mathrm{~m} / \mathrm{s})$

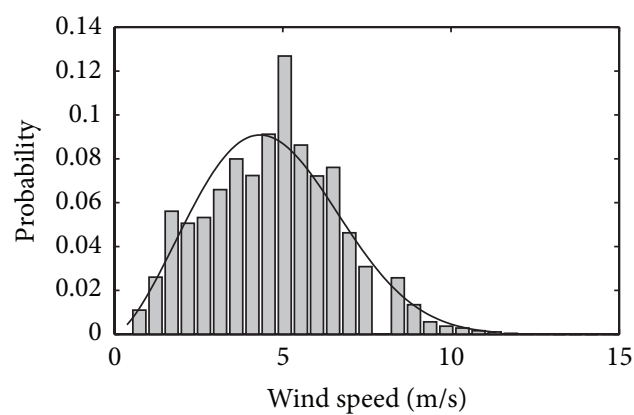

Data

Weibull

(g) July $(\bar{v}=4.59 \mathrm{~m} / \mathrm{s})$
Data

- Weibull

(d) April ( $\bar{v}=3.37 \mathrm{~m} / \mathrm{s})$

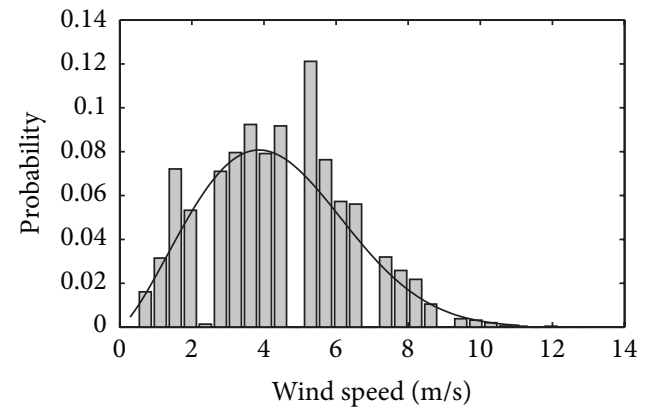

$\square$ Data

Weibull

(f) June $(\bar{v}=4.18 \mathrm{~m} / \mathrm{s})$

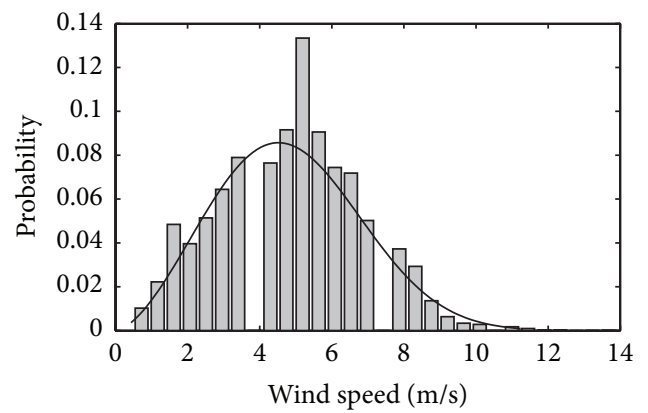

Data

Weibull

(h) August ( $\bar{v}=4.70 \mathrm{~m} / \mathrm{s})$

FIgURE 4: Continued. 


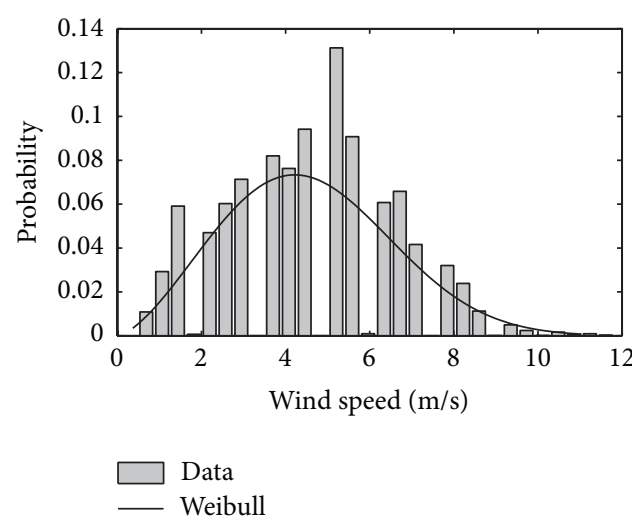

(i) September $(\bar{v}=4.45 \mathrm{~m} / \mathrm{s})$

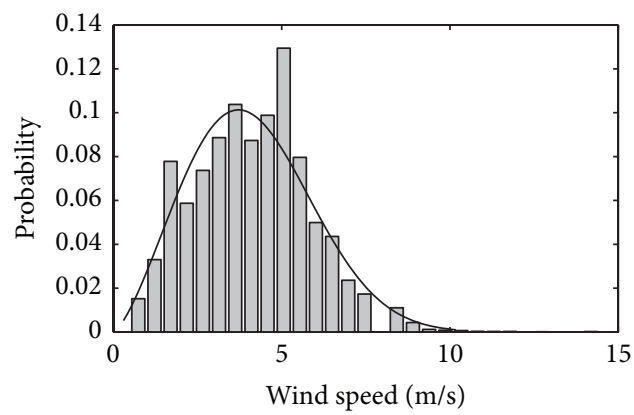

Data

Weibull

(k) November $(\bar{v}=3.94 \mathrm{~m} / \mathrm{s})$

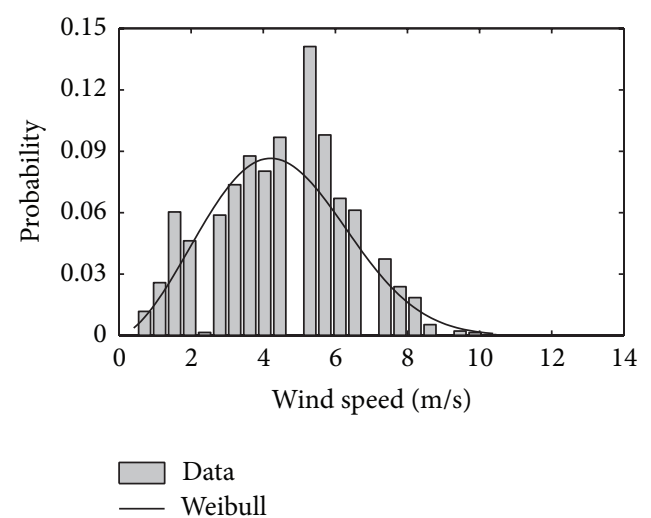

(j) October $(\bar{v}=4.33 \mathrm{~m} / \mathrm{s})$

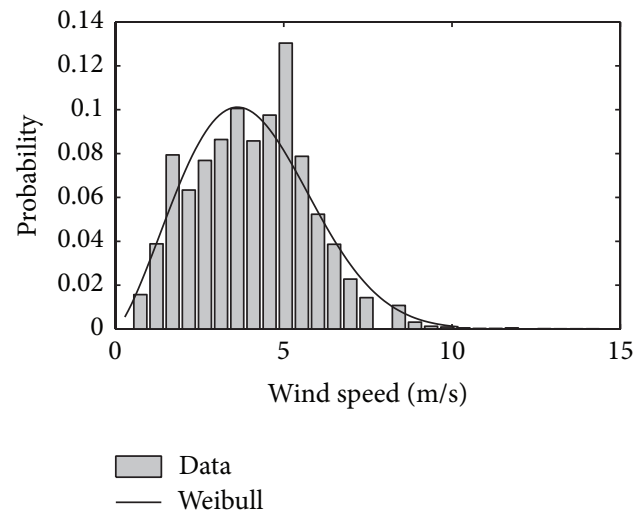

(l) December $(\bar{v}=3.86 \mathrm{~m} / \mathrm{s})$

FIgURE 4: Weibull distribution curves fitted to wind speed data at Plaisance at $10 \mathrm{~m}$ above ground level, from January to December (1973-2013). The mean value for the data is also displayed.

TABle 2: Statistical description of wind data for Plaisance and Vacoas.

\begin{tabular}{lcc}
\hline \multirow{2}{*}{ Statistics } & \multicolumn{2}{c}{ Estimates $(\mathrm{m} / \mathrm{s})$} \\
& Plaisance & Vacoas \\
\hline Mean $(\bar{v})$ & 4.05 & 3.57 \\
Standard Deviation $(\mathrm{SD})$ & 1.79 & 1.61 \\
Minimum value $\left(v_{\min }\right)$ & 0.07 & 0.08 \\
Maximum value $\left(v_{\max }\right)$ & 30.40 & 37.60 \\
\hline
\end{tabular}

the effects of wind gusts in the analysis. The focus is to study wind power on a normal day. This maximum allowed the value of wind speed to be based on the cut-off speed of most small-wind turbines.

4.1. Monthly Probability Density of Wind Speeds. The probability distribution of wind speed is needed in evaluating the potential of wind power at different sites. Hence the selection of appropriate wind turbines can be made to obtain optimum results. Figures 4 and 5 show the monthly histograms of recorded wind speeds along with the fitted Weibull wind speed distributions. The mean wind speed value is also displayed in each case. The observed frequency rises steadily reaching a maximum value for wind speed between 3 and
$4 \mathrm{~m} / \mathrm{s}$, and then it drops gradually. The Weibull curves peak near the mean value of the velocity. The similarity of both trends shows a good representation given by the Weibull model when compared to the actual data. Plaisance, which is near the sea, benefits more from wind presence at a velocity higher than that of Vacoas which is on the mainland. It can be observed for both locations that the winter months, April to September, yield higher wind speeds than the summer months. It should be noted that, year round, the island is influenced by the southeast trade winds. This is strengthened during the winter period when the Arctic oscillation is in its warm phase and the trade winds reach their highest value as compared to the summer period. Hence the wind speeds tend to increase during the winter period.

Tables 3 and 4 show the monthly variation of the Weibull parameters for Plaisance and Vacoas, at a height of $10 \mathrm{~m}$ above ground level, for each ten-year period from 1973 to 2013 for Plaisance and 1977 to 2013 for Vacoas. It can be observed that, for Vacoas, the Weibull scale parameter $c$ varies between $3.45 \mathrm{~m} / \mathrm{s}$ and $5.02 \mathrm{~m} / \mathrm{s}$ while for Plaisance it varies between $4.48 \mathrm{~m} / \mathrm{s}$ and $5.45 \mathrm{~m} / \mathrm{s}$. The shape parameter $k$ for Vacoas varies between 1.45 and 2.86, and for Plaisance it varies between 1.86 and 3.71. For Plaisance the lowest value of $k$ is in the month of February (1973-2013) and for Vacoas, it is lowest in January (1977-1986). For both locations the highest 

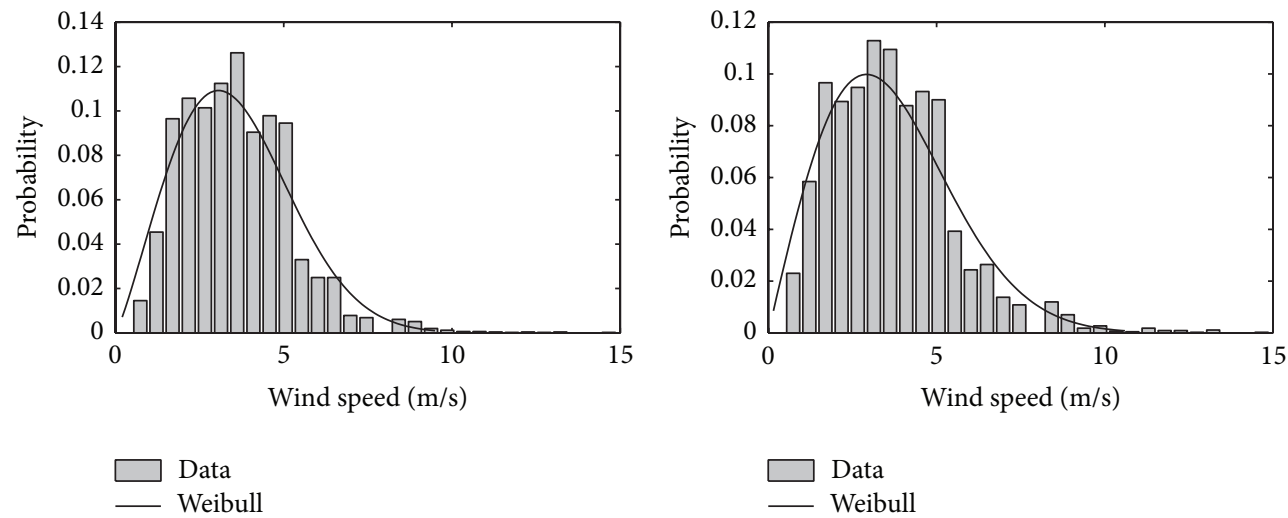

(a) January $(\bar{v}=3.41 \mathrm{~m} / \mathrm{s})$

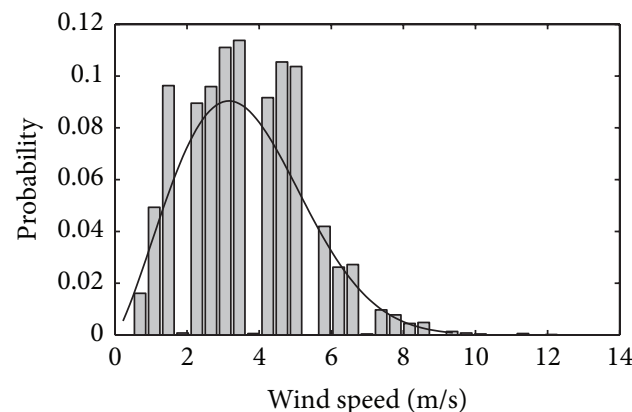

(b) February $(\bar{v}=3.44 \mathrm{~m} / \mathrm{s})$
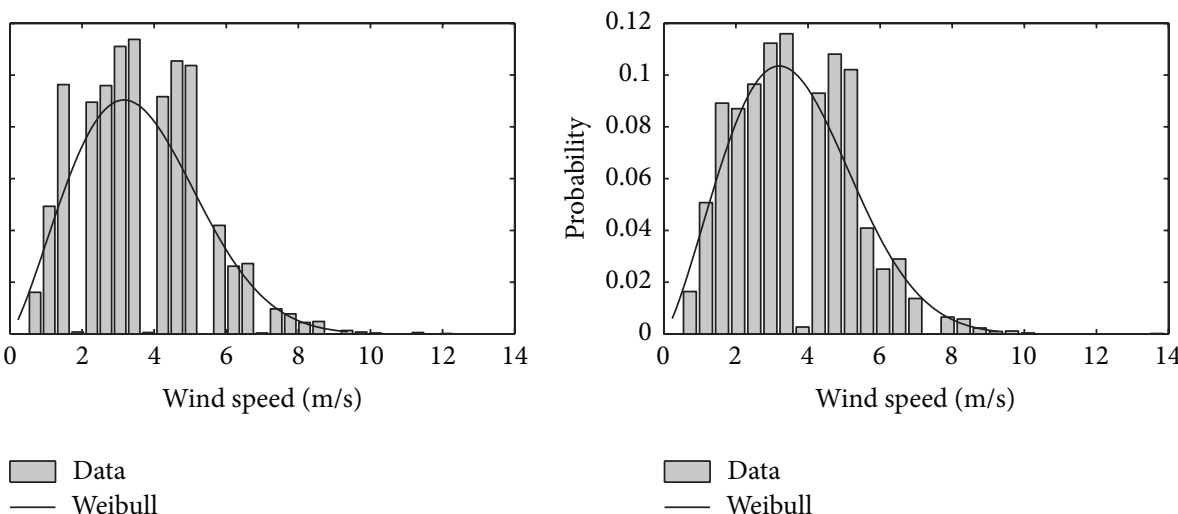

(c) $\operatorname{March}(\bar{v}=3.45 \mathrm{~m} / \mathrm{s})$
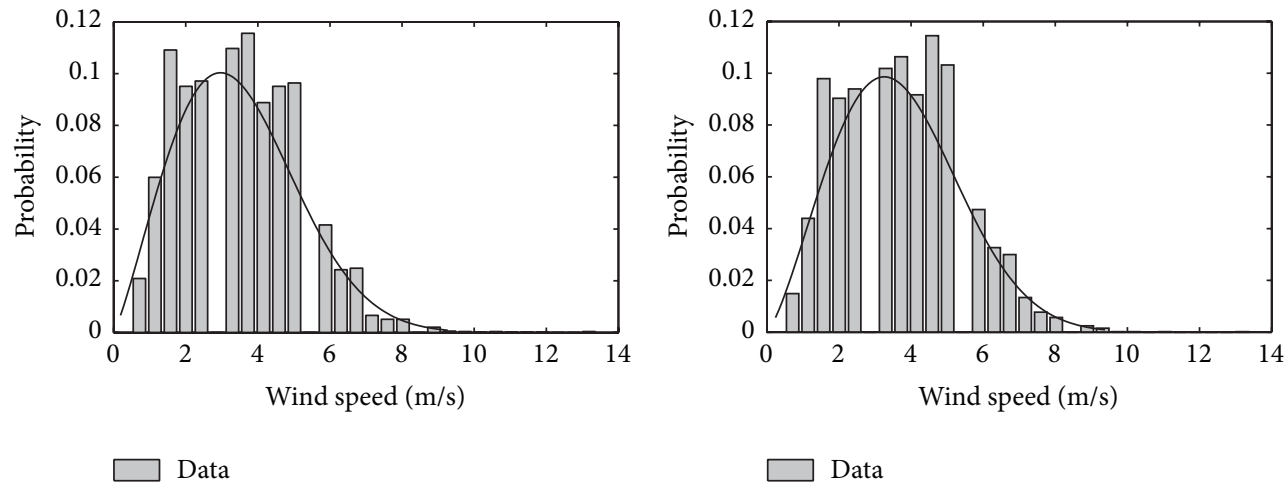

Weibull

(e) $\operatorname{May}(\bar{v}=3.27 \mathrm{~m} / \mathrm{s})$

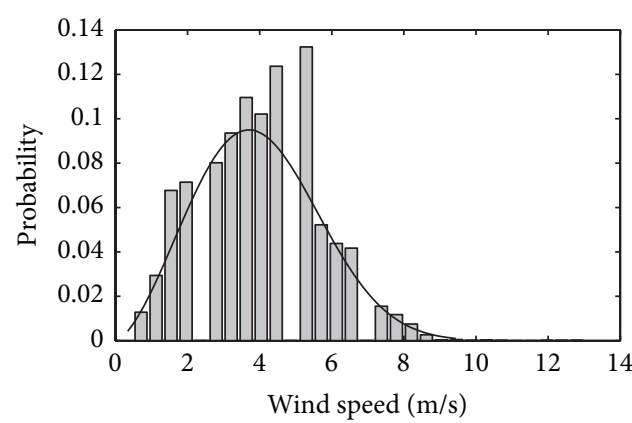

$\square$ Data

— Weibull

(f) June $(\bar{v}=3.55 \mathrm{~m} / \mathrm{s})$

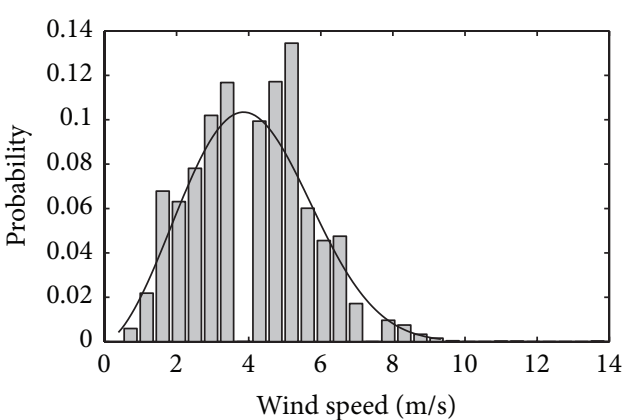

$\square$ Data

Weibull

Data

Weibull

(g) July $(\bar{v}=3.95 \mathrm{~m} / \mathrm{s})$

(h) August $(\bar{v}=4.01 \mathrm{~m} / \mathrm{s})$

FIgURE 5: Continued. 

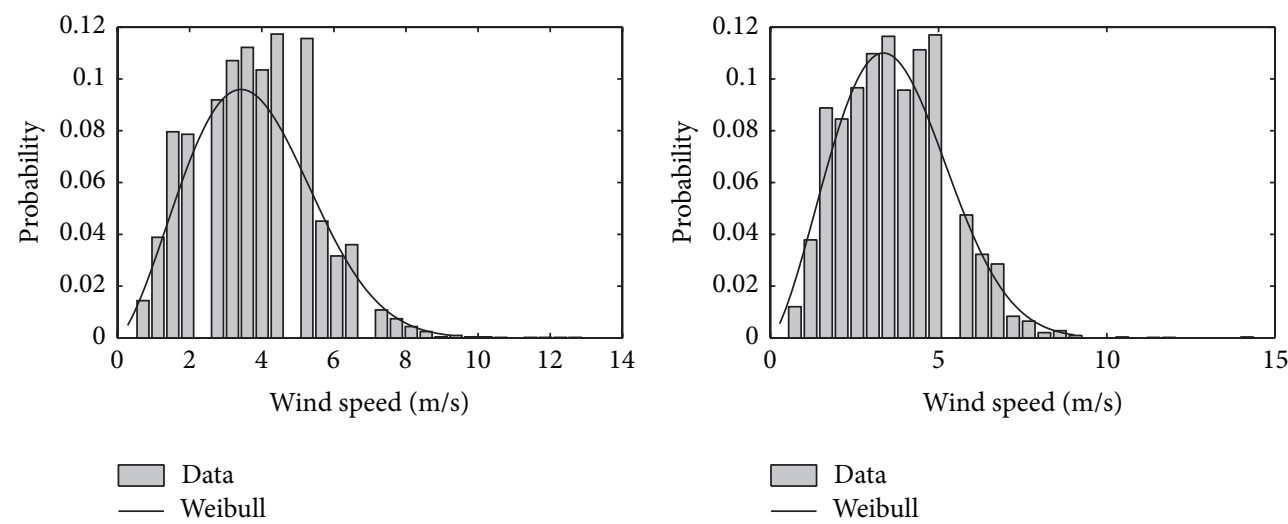

(i) September $(\bar{v}=3.70 \mathrm{~m} / \mathrm{s})$

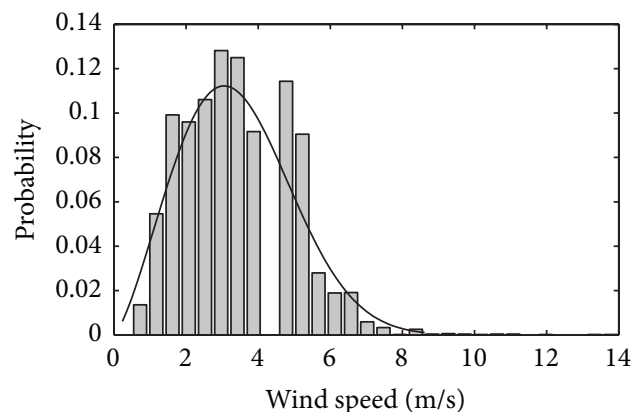

(j) October $(\bar{v}=3.62 \mathrm{~m} / \mathrm{s})$

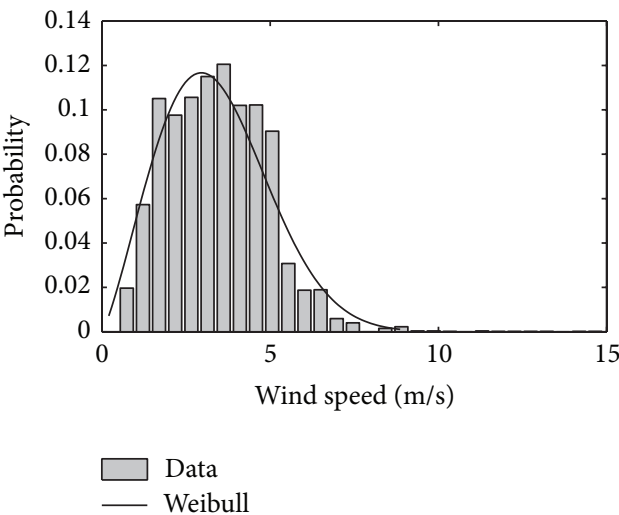

(l) December $(\bar{v}=3.26 \mathrm{~m} / \mathrm{s})$

FiguRE 5: Weibull distribution curves fitted to wind speed data at Vacoas at $10 \mathrm{~m}$ above ground level, from January to December (1977-2013). The mean value for the data is also displayed.

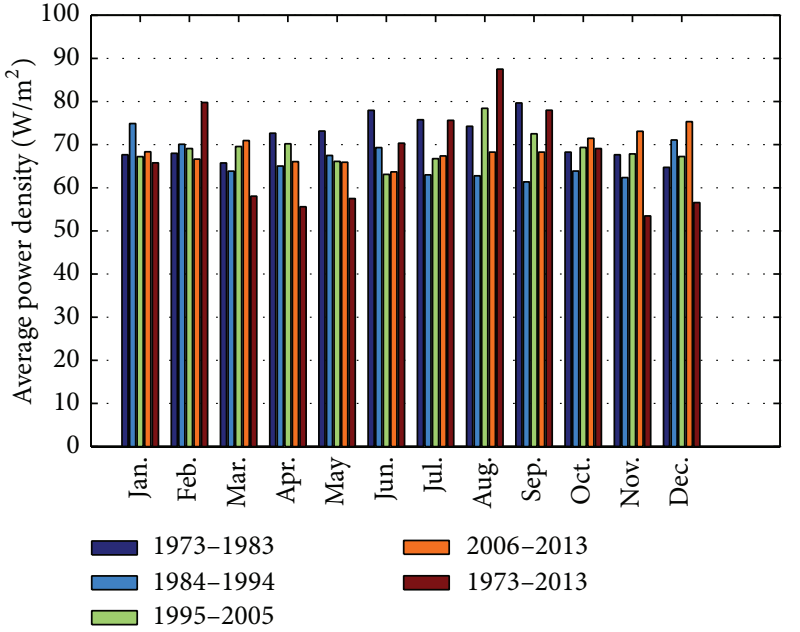

(a) Plaisance

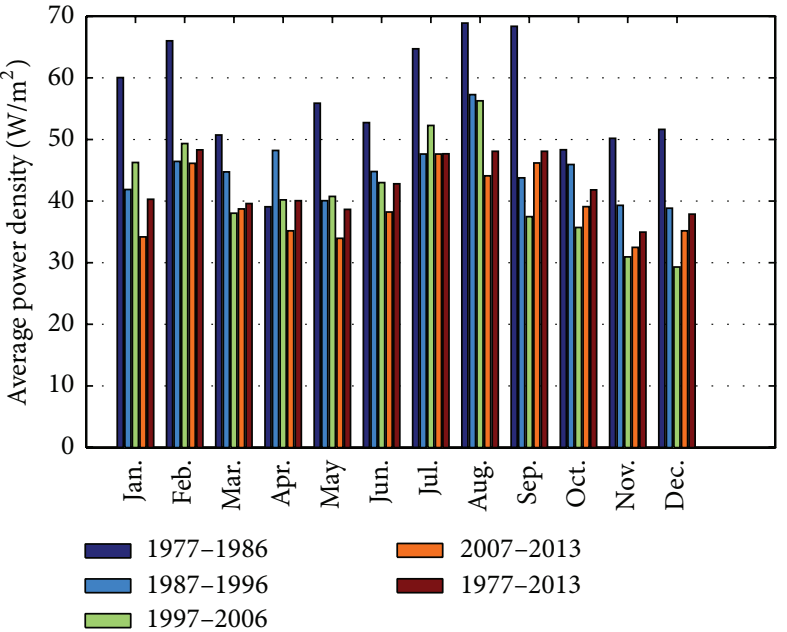

(b) Vacoas

FIGURE 6: Plot of monthly variations in wind power densities at $10 \mathrm{~m}$ above ground level.

value of $k$ is found in July (1973-2013 for Plaisance and 19771986 for Vacoas). The lowest value of $c$ at Plaisance is found in April (1973-2013) and for Vacoas it is in December (19972006). The highest value of $c$ is found in both July and August (1973-2013) for Plaisance and in July (1977-1986) for Vacoas.
Figure 6 displays the monthly variations of average power density at both locations. It can be observed that, throughout the whole year, the average power density for Plaisance varies between $50 \mathrm{~W} / \mathrm{m}^{2}$ and $90 \mathrm{~W} / \mathrm{m}^{2}$, with the peak in August (1973-2013). It is also noted that, for Vacoas, the average 
TABLE 3: Weibull parameters for monthly wind data at Plaisance at $10 \mathrm{~m}$ above ground level.

\begin{tabular}{|c|c|c|c|c|c|c|}
\hline Months & Parameters & $1973-1982$ & $1983-1992$ & $1993-2002$ & $2003-2013$ & 1973-2013 \\
\hline \multirow{2}{*}{ January } & $k(-)$ & 2.11 & 2.12 & 2.43 & 2.08 & 2.04 \\
\hline & $c(\mathrm{~m} / \mathrm{s})$ & 4.75 & 4.93 & 4.92 & 4.70 & 4.66 \\
\hline \multirow{2}{*}{ February } & $k(-)$ & 2.00 & 2.17 & 2.42 & 2.11 & 1.86 \\
\hline & $c(\mathrm{~m} / \mathrm{s})$ & 4.68 & 4.85 & 4.96 & 4.73 & 4.80 \\
\hline \multirow{2}{*}{ March } & $k(-)$ & 2.07 & 2.30 & 2.40 & 2.15 & 2.11 \\
\hline & $c(\mathrm{~m} / \mathrm{s})$ & 4.68 & 4.78 & 4.97 & 4.86 & 4.51 \\
\hline \multirow{2}{*}{ April } & $k(-)$ & 1.90 & 2.26 & 2.50 & 2.17 & 2.16 \\
\hline & $c(\mathrm{~m} / \mathrm{s})$ & 4.69 & 4.78 & 5.03 & 4.75 & 4.48 \\
\hline \multirow{2}{*}{ May } & $k(-)$ & 2.14 & 2.23 & 2.42 & 2.20 & 2.14 \\
\hline & $c(\mathrm{~m} / \mathrm{s})$ & 4.90 & 4.83 & 4.90 & 4.77 & 4.52 \\
\hline \multirow{2}{*}{ June } & $k(-)$ & 1.98 & 2.24 & 2.50 & 2.30 & 2.32 \\
\hline & $c(\mathrm{~m} / \mathrm{s})$ & 4.88 & 4.88 & 4.85 & 4.77 & 4.94 \\
\hline \multirow{2}{*}{ July } & $k(-)$ & 2.02 & 2.36 & 2.44 & 2.20 & 3.71 \\
\hline & $c(\mathrm{~m} / \mathrm{s})$ & 4.86 & 4.79 & 4.92 & 4.81 & 5.45 \\
\hline \multirow{2}{*}{ August } & $k(-)$ & 2.18 & 2.38 & 2.25 & 2.14 & 2.59 \\
\hline & $c(\mathrm{~m} / \mathrm{s})$ & 4.95 & 4.79 & 5.09 & 4.79 & 5.45 \\
\hline \multirow{2}{*}{ September } & $k(-)$ & 2.16 & 2.43 & 2.49 & 2.14 & 2.46 \\
\hline & $c(\mathrm{~m} / \mathrm{s})$ & 5.05 & 4.78 & 5.08 & 4.79 & 5.19 \\
\hline \multirow{2}{*}{ October } & $k(-)$ & 2.23 & 2.25 & 2.46 & 2.14 & 2.61 \\
\hline & $c(\mathrm{~m} / \mathrm{s})$ & 4.85 & 4.75 & 4.99 & 4.86 & 5.05 \\
\hline \multirow{2}{*}{ November } & $k(-)$ & 1.97 & 2.27 & 2.43 & 2.13 & 2.68 \\
\hline & $c(\mathrm{~m} / \mathrm{s})$ & 4.64 & 4.72 & 4.94 & 4.89 & 4.66 \\
\hline \multirow{2}{*}{ December } & $k(-)$ & 2.05 & 2.36 & 2.52 & 2.04 & 2.30 \\
\hline & $c(\mathrm{~m} / \mathrm{s})$ & 4.64 & 4.98 & 4.97 & 4.87 & 4.59 \\
\hline
\end{tabular}

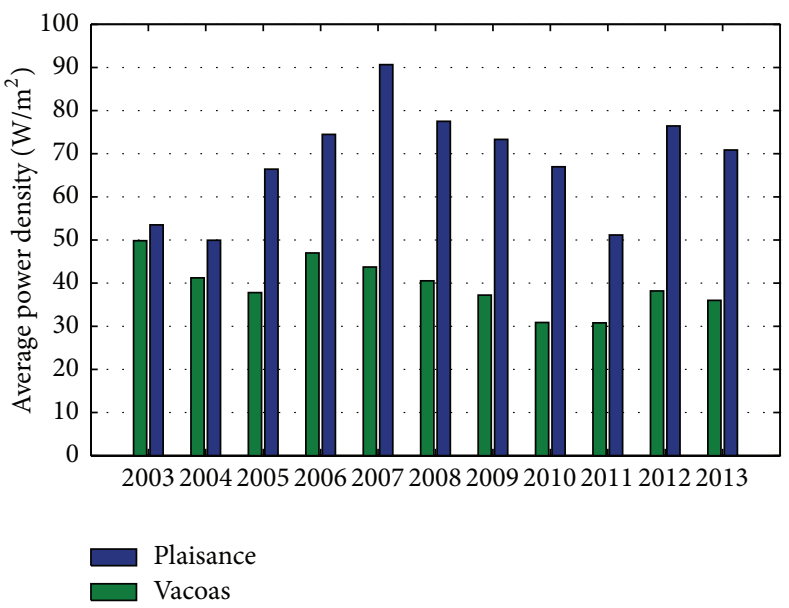

FIGURE 7: Yearly variations in wind power densities at Plaisance and Vacoas at $10 \mathrm{~m}$ above ground level, from 2003 to 2013.

power density varies between $30 \mathrm{~W} / \mathrm{m}^{2}$ and $70 \mathrm{~W} / \mathrm{m}^{2}$ with peaks observed in January, February, July, August, and September (1977-1986). In general, the mean power density is higher in the winter season (April to September) and lower in summer (October to March).

4.2. Mean Wind Power Density for the Period 2003 to 2013. Table 5 displays the shape and scale parameter of Weibull at Plaisance and Vacoas for the period 2003 to 2013. At Plaisance the $k$ parameter varies from 1.97 to 2.44 while for Vacoas it varies between 2.17 and 2.80. The scale parameter at Plaisance varies between $4.25 \mathrm{~m} / \mathrm{s}$ and $5.26 \mathrm{~m} / \mathrm{s}$ and between $3.82 \mathrm{~m} / \mathrm{s}$ and $4.37 \mathrm{~m} / \mathrm{s}$ at Vacoas. Figure 7 displays the variations of average wind power density for the period of 2003-2013. In general, the wind power density for Vacoas varies between $30 \mathrm{~W} / \mathrm{m}^{2}$ and $50 \mathrm{~W} / \mathrm{m}^{2}$. For Plaisance it varies between $50 \mathrm{~W} / \mathrm{m}^{2}$ and $90 \mathrm{~W} / \mathrm{m}^{2}$. Year 2007 has yielded the maximum power at $90 \mathrm{~W} / \mathrm{m}^{2}$ at a $10 \mathrm{~m}$ height and the lowest recorded 
TABLE 4: Weibull parameters for monthly wind data at Vacoas at $10 \mathrm{~m}$ above ground level.

\begin{tabular}{|c|c|c|c|c|c|c|}
\hline Months & Parameters & $1977-1986$ & 1987-1996 & 1997-2006 & 2007-2013 & 1977-2013 \\
\hline \multirow{2}{*}{ January } & $k(-)$ & 1.45 & 2.13 & 2.05 & 2.43 & 2.19 \\
\hline & $c(\mathrm{~m} / \mathrm{s})$ & 3.84 & 4.05 & 4.15 & 3.93 & 4.04 \\
\hline \multirow{2}{*}{ February } & $k(-)$ & 1.55 & 1.87 & 2.25 & 1.89 & 2.04 \\
\hline & $c(\mathrm{~m} / \mathrm{s})$ & 4.12 & 4.01 & 4.36 & 4.02 & 4.20 \\
\hline \multirow{2}{*}{ March } & $k(-)$ & 2.18 & 2.27 & 2.22 & 2.31 & 2.32 \\
\hline & $c(\mathrm{~m} / \mathrm{s})$ & 4.36 & 4.23 & 3.98 & 4.05 & 4.08 \\
\hline \multirow{2}{*}{ April } & $k(-)$ & 1.92 & 2.28 & 2.19 & 2.47 & 2.30 \\
\hline & $c(\mathrm{~m} / \mathrm{s})$ & 3.83 & 4.34 & 4.04 & 3.98 & 4.09 \\
\hline \multirow{2}{*}{ May } & $k(-)$ & 2.61 & 2.37 & 1.91 & 2.13 & 2.21 \\
\hline & $c(\mathrm{~m} / \mathrm{s})$ & 4.70 & 4.12 & 3.88 & 3.79 & 4.00 \\
\hline \multirow{2}{*}{ June } & $k(-)$ & 2.85 & 2.22 & 2.17 & 2.46 & 2.33 \\
\hline & $c(\mathrm{~m} / \mathrm{s})$ & 4.68 & 4.20 & 4.12 & 4.09 & 4.20 \\
\hline \multirow{2}{*}{ July } & $k(-)$ & 2.86 & 2.42 & 2.68 & 2.53 & 2.45 \\
\hline & $c(\mathrm{~m} / \mathrm{s})$ & 5.02 & 4.39 & 4.62 & 4.43 & 4.40 \\
\hline \multirow{2}{*}{ August } & $k(-)$ & 2.50 & 2.46 & 2.60 & 2.82 & 2.39 \\
\hline & $c(\mathrm{~m} / \mathrm{s})$ & 5.00 & 4.68 & 4.71 & 4.41 & 4.39 \\
\hline \multirow{2}{*}{ September } & $k(-)$ & 2.50 & 2.24 & 2.36 & 2.67 & 2.39 \\
\hline & $c(\mathrm{~m} / \mathrm{s})$ & 4.98 & 4.18 & 4.02 & 4.43 & 4.39 \\
\hline \multirow{2}{*}{ October } & $k(-)$ & 2.21 & 2.40 & 2.28 & 2.73 & 2.38 \\
\hline & $c(\mathrm{~m} / \mathrm{s})$ & 4.31 & 4.33 & 3.93 & 4.21 & 4.18 \\
\hline \multirow{2}{*}{ November } & $k(-)$ & 2.14 & 2.09 & 2.15 & 2.60 & 2.29 \\
\hline & $c(\mathrm{~m} / \mathrm{s})$ & 4.32 & 3.95 & 3.68 & 3.92 & 3.90 \\
\hline \multirow{2}{*}{ December } & $k(-)$ & 2.40 & 1.96 & 1.91 & 2.69 & 2.27 \\
\hline & $c(\mathrm{~m} / \mathrm{s})$ & 4.50 & 3.85 & 3.45 & 4.05 & 4.00 \\
\hline
\end{tabular}

TABLE 5: Weibull parameters for yearly wind data at Plaisance and Vacoas at $10 \mathrm{~m}$ above ground level.

\begin{tabular}{|c|c|c|c|}
\hline Year & Parameter & Plaisance & Vacoas \\
\hline \multirow{2}{*}{2003} & $k(-)$ & 2.19 & 2.24 \\
\hline & $c(\mathrm{~m} / \mathrm{s})$ & 4.45 & 4.37 \\
\hline \multirow{2}{*}{2004} & $k(-)$ & 2.32 & 2.50 \\
\hline & $c(\mathrm{~m} / \mathrm{s})$ & 4.41 & 4.21 \\
\hline \multirow{2}{*}{2005} & $k(-)$ & 2.10 & 2.44 \\
\hline & $c(\mathrm{~m} / \mathrm{s})$ & 4.71 & 4.07 \\
\hline \multirow{2}{*}{2006} & $k(-)$ & 2.44 & 2.40 \\
\hline & $c(\mathrm{~m} / \mathrm{s})$ & 5.10 & 4.36 \\
\hline \multirow{2}{*}{2007} & $k(-)$ & 2.14 & 2.19 \\
\hline & $c(\mathrm{~m} / \mathrm{s})$ & 5.26 & 4.16 \\
\hline \multirow{2}{*}{2008} & $k(-)$ & 2.18 & 2.42 \\
\hline & $c(\mathrm{~m} / \mathrm{s})$ & 5.02 & 4.16 \\
\hline \multirow{2}{*}{2009} & $k(-)$ & 2.05 & 2.51 \\
\hline & $c(\mathrm{~m} / \mathrm{s})$ & 4.84 & 4.07 \\
\hline \multirow{2}{*}{2010} & $k(-)$ & 2.17 & 2.59 \\
\hline & $c(\mathrm{~m} / \mathrm{s})$ & 4.77 & 3.85 \\
\hline \multirow{2}{*}{2011} & $k(-)$ & 2.00 & 2.51 \\
\hline & $c(\mathrm{~m} / \mathrm{s})$ & 4.25 & 3.82 \\
\hline \multirow{2}{*}{2012} & $k(-)$ & 2.30 & 2.80 \\
\hline & $c(\mathrm{~m} / \mathrm{s})$ & 5.07 & 4.19 \\
\hline \multirow{2}{*}{2013} & $k(-)$ & 1.97 & 2.17 \\
\hline & $c(\mathrm{~m} / \mathrm{s})$ & 4.71 & 3.88 \\
\hline
\end{tabular}

power was found at $52 \mathrm{~W} / \mathrm{m}^{2}$ in 2004 . Additionally, it was noted that the year 2003 yielded a maximum power density of $50 \mathrm{~W} / \mathrm{m}^{2}$ while the years 2010 and 2011 recorded the lowest power density which was at around $32 \mathrm{~W} / \mathrm{m}^{2}$.

4.3. Performance of Some Small-Wind Turbines. To have an estimate of the performance of wind turbines at Vacoas and Plaisance, six small commercial wind turbines were selected. These turbines were considered owing to their good performance and reasonable cost. The characteristic properties of these wind turbines are listed in Table 6 and Figure 8 displays the power of turbine versus wind speed as given by the manufacturer in the turbine's manual. The propeller axis for the Exmok $1.5 \mathrm{~kW}$ wind turbine is horizontal while it is vertical for the remaining wind turbines.

The energy output for the year 2013 was analyzed in this case for both sites. Figure 9 displays the yearly wind energy output by the six wind generators at different heights at Plaisance and Vacoas. The power values for hub heights above $10 \mathrm{~m}$ were computed after extrapolating the Weibull parameters using (9). It is noted that the diagrams have the same general shape but differ from each site owing to the type of wind influencing the regions under study. At $10 \mathrm{~m}$ above ground level the yearly energy production from the bigger wind generators is relatively weak as it lies below $15000 \mathrm{kWh} /$ year for Plaisance and less than $1000 \mathrm{kWh} /$ year for Vacoas (Figure 9). The energy output increases by nearly 
TABLE 6: Main characteristics of six small commercial wind turbines.

\begin{tabular}{lcccccc}
\hline Characteristics & Aeolos & Eddy GT & Exmok & SRM & WindSpot \\
\hline Rated power $(\mathrm{kW})$ & 1 & 3 & 1 & 1.5 & 12 & 3 \\
Hub height $(\mathrm{m})$ & 9 & 9 & 12 & 8.1 & 12 & 12.6 \\
Swept area $\left(\mathrm{m}^{2}\right)$ & 8.1 & 19.6 & 4.62 & 2.5 & 3 & 8.9 \\
Cut-in wind speed $(\mathrm{m} / \mathrm{s}), V_{\text {in }}$ & 3 & 3 & 3.5 & 17 & 3 \\
Cut-off wind speed (m/s), $V_{\text {out }}$ & 25 & 25 & 12 & 9 & 20 & 10 \\
Rated wind speed $(\mathrm{m} / \mathrm{s})$ & 10 & 10 & & & 12
\end{tabular}

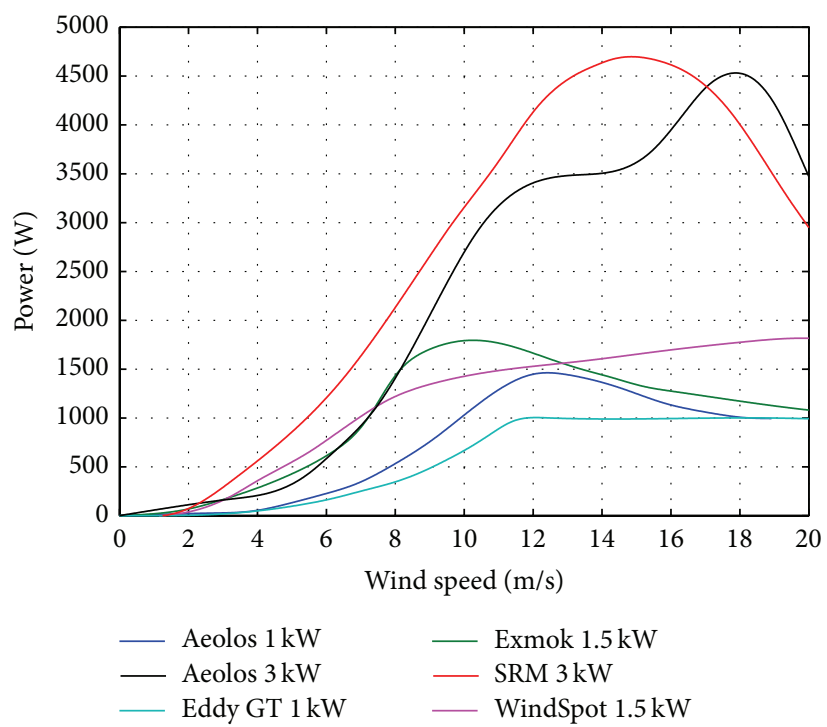

FIgURE 8: Power curve of six commercial wind turbines operating in the range from 1 to $3 \mathrm{~kW}$.

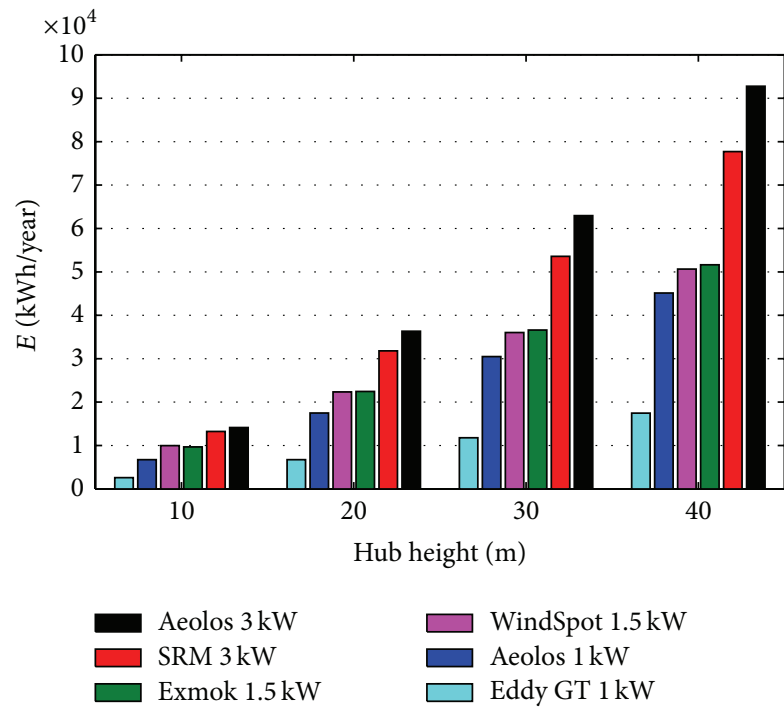

(a) Plaisance

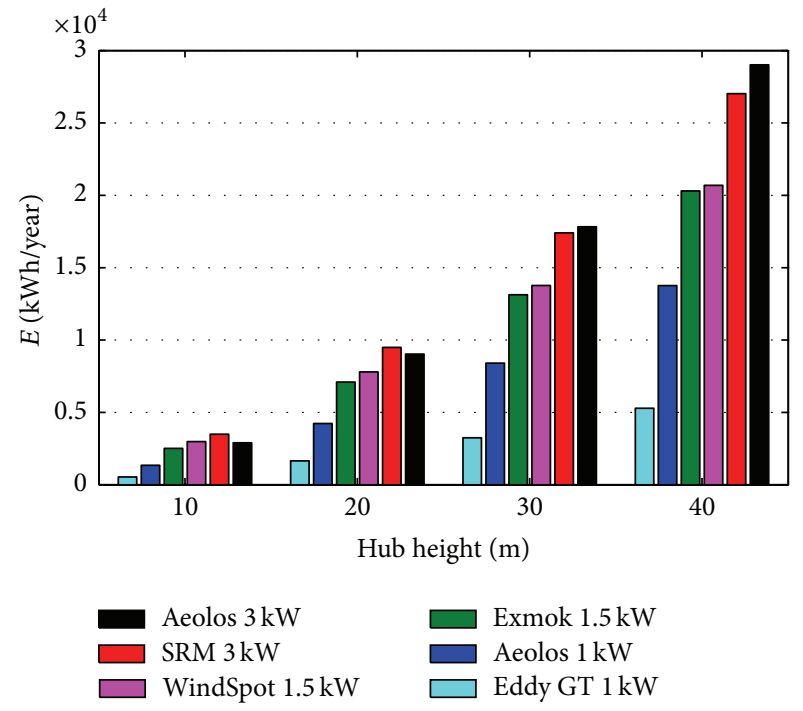

(b) Vacoas

FIGURE 9: Yearly wind energy output of the six wind turbines at different heights above ground level.

$15 \%$ for the bigger generators on increasing hub height to a $40 \mathrm{~m}$ height at both locations.

\section{Conclusion}

In this study, the wind potential analysis was performed for two specific locations in Mauritius: Plaisance and Vacoas.
The MLE method was employed to compute the Weibull $k$ and $c$ parameters that describe the wind speed data. A good correlation was obtained between the fitted data and the Weibull distribution for each case studied. Monthly and yearly analysis were performed at both locations, and it was noted that Plaisance has generally a high wind speed 
throughout the year while Vacoas has high wind speed in July. For both sites, the maximum power yielded was found to be during the winter period. The performances of six commercial wind turbines were also studied for that area and results showed that at higher altitudes the Aeolos $3 \mathrm{~kW}$ wind turbine yielded the most important energy output.

\section{Conflict of Interests}

The authors declare no conflict of interests regarding the publication of this paper.

\section{Acknowledgments}

The authors would like to thank the Utah Climate Center for the meteorological data provision. Also gratitude is expressed to the University of Mauritius for providing facilities for research and the Mauritius Research Council for the funding of this project. Special thanks are extended to the HRDR funds, the Project Coordinator, Dr. G.K. Beeharry, Research Assistant Mr. Vinand Prayag, and SCAP consultants Michelle Willmers and Henry Trotter.

\section{References}

[1] S. Mauritius, "Annual digest of statistics 2010," Tech. Rep., Central Statistics Office, Ministry of Finance and Economic Development, 2010.

[2] CEB, “Integrated electricity plan 2013-2022," Tech. Rep., Central Electricity Board, Curepipe, Mauritius, 2013.

[3] M. Commission, Maurice Ile Durable, June 2015, http://www .govmu.org/portal/sites/mid/aboutMID.htm.

[4] E. W. EECA, Power from the People: A Guide to Micro-Generation, EECA, 2010.

[5] A. Gagliano, F. Nocera, F. Patania, and A. Capizzi, "Assessment of micro-wind turbines performance in the urban environments: an aided methodology through geographical information systems," International Journal of Energy and Environmental Engineering, vol. 4, no. 1, pp. 1-14, 2013.

[6] A. Z. Dhunny, M. R. Lollchund, R. Boojhawon, and S. D. D. V. Rughooputh, "Statistical modelling of wind speed data for mauritius," International Journal of Renewable Energy Research, vol. 4, no. 4, pp. 1056-1064, 2014.

[7] M. R. Mirghaed and R. Roshandel, "Site specific optimization of wind turbines energy cost: iterative approach," Energy Conversion and Management, vol. 73, pp. 167-175, 2013.

[8] W. Zghal, G. Kantchev, and H. Kchaou, "Determination of recoverable wind energy for electricity generation using wind energy conversion system in Tunisia," International Journal of Engineering, Science and Technology, vol. 3, no. 5, 2011.

[9] B. Sahin, M. Bilgili, and H. Akilli, "The wind power potential of the eastern Mediterranean region of Turkey," Journal of Wind Engineering and Industrial Aerodynamics, vol. 93, no. 2, pp. 171183, 2005.

[10] G. M. Ngala, B. Alkali, and M. A. Aji, "Viability of wind energy as a power generation source in Maiduguri, Borno state, Nigeria," Renewable Energy, vol. 32, no. 13, pp. 2242-2246, 2007.

[11] A. Ucar and F. Balo, "Investigation of wind characteristics and assessment of wind-generation potentiality in Uludağ-Bursa, Turkey," Applied Energy, vol. 86, no. 3, pp. 333-339, 2009.
[12] A. Keyhani, M. Ghasemi-Varnamkhasti, M. Khanali, and R. Abbaszadeh, "An assessment of wind energy potential as a power generation source in the capital of Iran, Tehran," Energy, vol. 35, no. 1, pp. 188-201, 2010.

[13] A. R. Jiménez, J. A. Diazgranados, and M. T. A. AMorantes, "Electricity generation and wind potential assessment in regions of Colombia," Dyna, vol. 79, no. 171, pp. 116-122, 2011.

[14] L. A. Lehri, S. M. Shah, B. A. Leghari, and M. I. Tareen, "Wind potential assessment and optimization of wind turbine blade for coastal area of Jiwani Balochistan Pakistan," International Journal of Materials, Mechanics and Manufacturing, vol. 1, no. 2, pp. 177-180, 2013.

[15] K. A. Abed and A. A. El-Mallah, "Capacity factor of wind turbines," Energy, vol. 22, no. 5, pp. 487-491, 1997.

[16] N. R. Mann, R. E. Schafer, and N. D. Singpurwalla, Methods for Statistical Analysis of Reliability and Life Data, John Wiley \& Sons, New York, NY, USA, 1974.

[17] Z. Şen, A. Altunkaynak, and T. Erdik, "Wind velocity vertical extrapolation by extended power law," Advances in Meteorology, vol. 2012, Article ID 178623, 6 pages, 2012.

[18] I. Youm, J. Sarr, M. Sall, A. Ndiaye, and M. M. Nane, "Analysis of wind data and wind energy potential along the northern coast of Senegal," Renewable and Sustainable Energy Reviews, vol. 8, pp. 95-108, 2005.

[19] S. O. Oyedepo, M. S. Adaramola, and S. S. Paul, "Analysis of wind speed data and wind energy potential in three selected locations in South-East Nigeria," International Journal of Energy and Environmental Engineering, vol. 3, no. 1, pp. 1-11, 2012.

[20] F. Y. Ettoumi, A. E. H. Adane, M. L. Benzaoui, and N. Bouzergui, "Comparative simulation of wind park design and siting in Algeria," Renewable Energy, vol. 33, no. 10, pp. 2333-2338, 2008.

[21] Mauritus Meterorological Services, 2015, http://metservice.intnet.mu/tropical-cyclone/warning-system.php.

[22] AWS, Wind Resource Assessment Handbook Fundamentals for Conducting a Successful Monitoring Program, 1997.

[23] F. Beaufort, Beaufort Wind Scale, July 2015, http://www.spc.noaa.gov/faq/tornado/beaufort.html. 


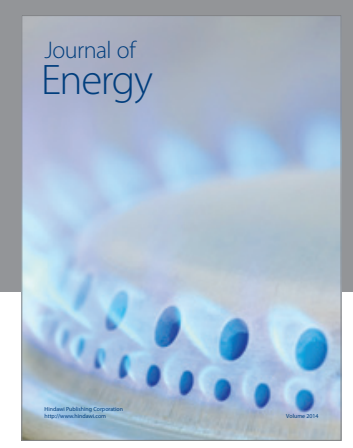

Journal of

Industrial Engineering
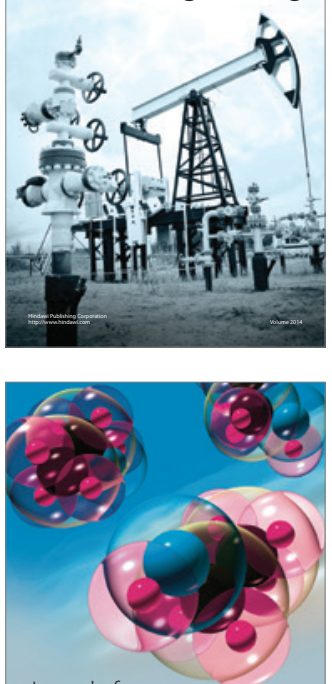

Fuels
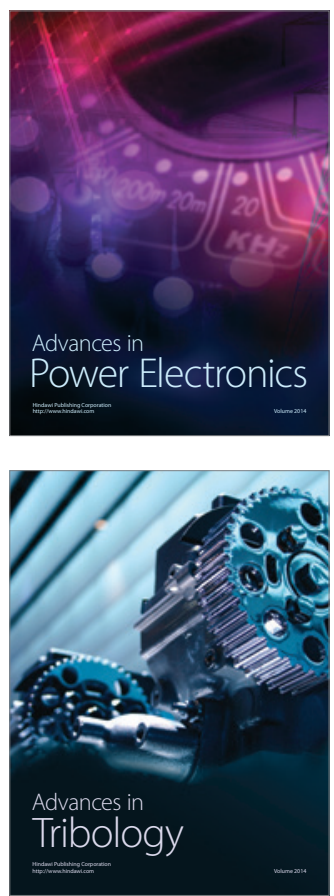

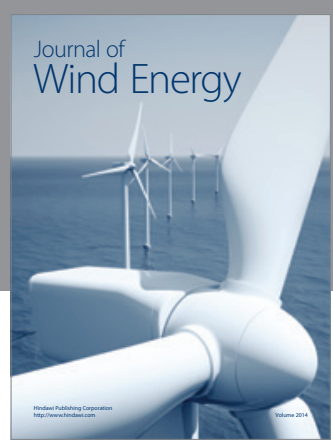

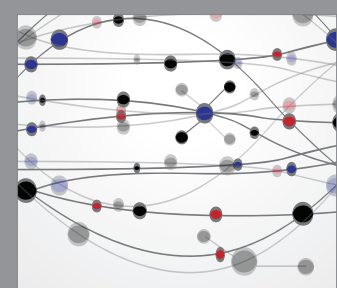

The Scientific World Journal

Submit your manuscripts at http://www.hindawi.com

Journal of

Structures
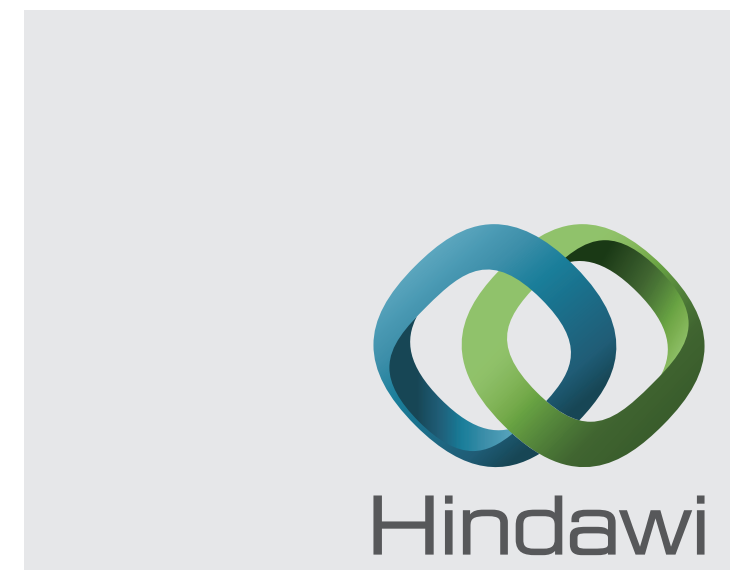

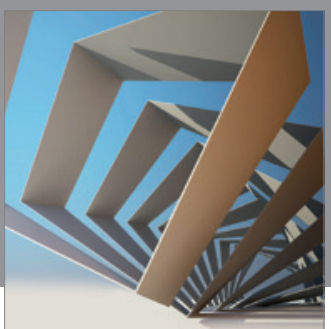

Rotating

Machinery
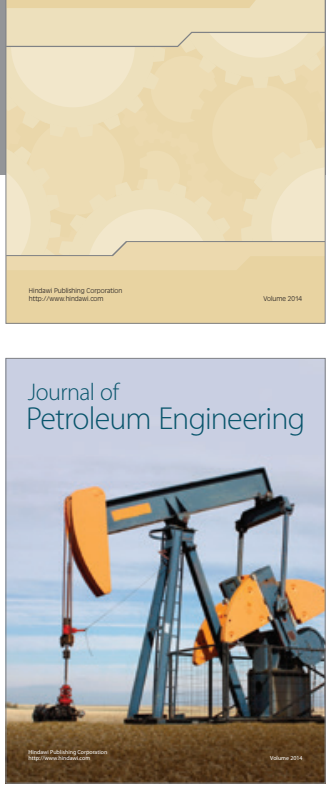

Journal of

Solar Energy
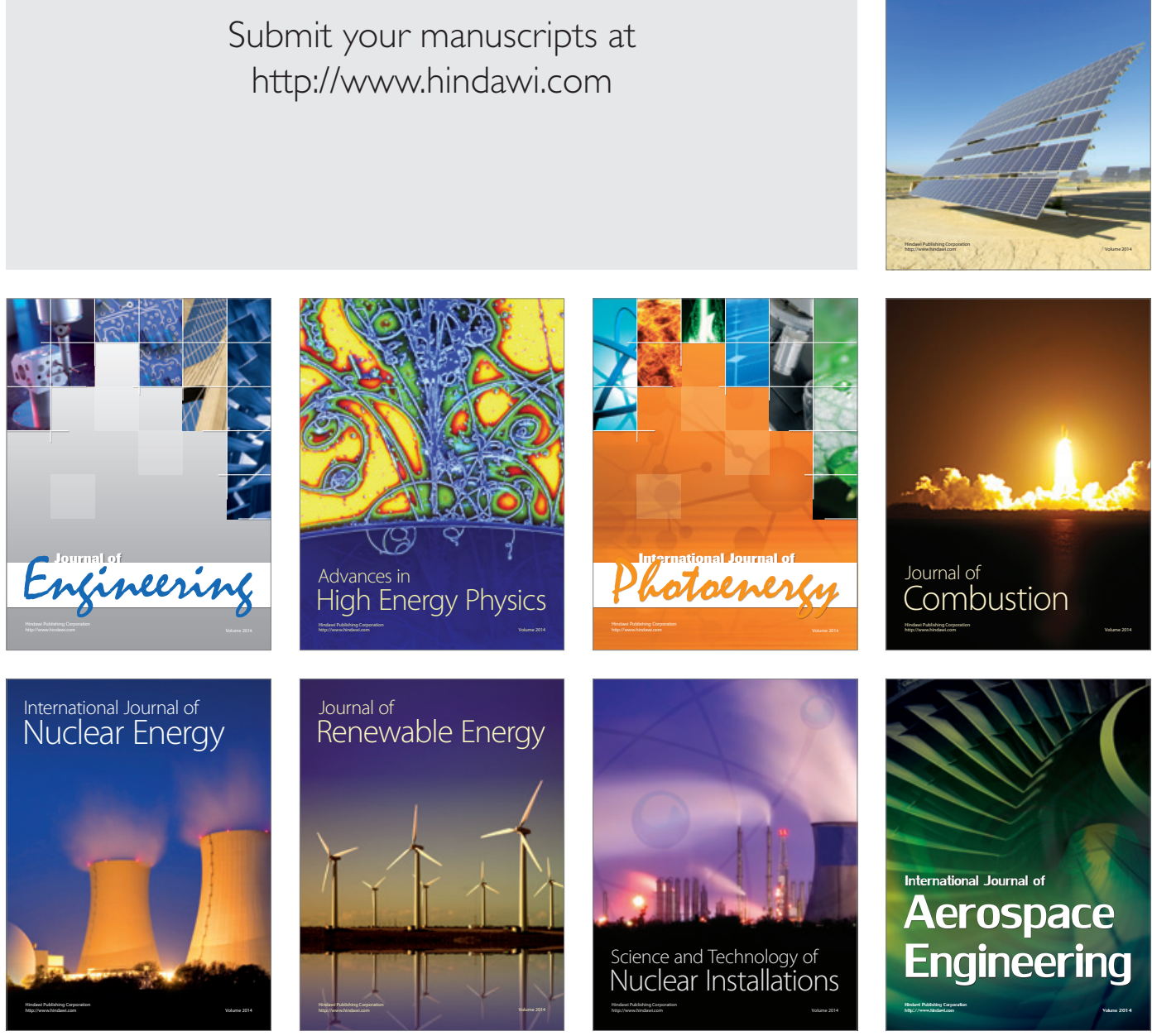